\title{
Pavel Chernovalov
}

- Brest State Technical University

- email: czernowalow@gmail.com

- ORCID: 0000-0003-0241-4613

\section{Zanna Chernovalova}

- Brest State A.S. Pushkin University

- e-mail: czr.zanna@gmail.com

- ORCID: 0000-0002-9966-0257

\section{METHODS OF FORMATION OF DIGITAL BIOCLUSTERS BASED ON LOGISTIC CHAINS OF BREST REGION}

\section{Abstract}

- Goal - the main purpose of this article is to substantiate the organizational capabilities of the formation of digital bioclusters in the Brest region. In this regard, the issues of building supply chains during the period of technological structure change are considered, especially on the basis of bioproduct specifics, since they become the most relevant in the general spectrum of scientific problems of economic theory and practice.

- Research methodology - the authors of the study focused on descriptive and monographic methods, cluster analysis and assessment of institutional effectiveness.

- Score/results - in this article, the authors present conclusions and results on the systematization of the whole complex of problems in the formation of supply chains of bioproducts and the possibility of the formation of bioclusters in the Brest region.

- Originality/value - the article presents original original material, since it is published for the first time and has a high potential for practical application, which leads to the presence of a corresponding added value within the framework of the study and confirms its scientific value.

| Key words: biotechnology, bioeconomics, clusters, logistics, digital technologies, supply chain. 


\section{Introduction}

The issues of biotechnologies within the framework of the 6th technological structure are currently first-priority and interesting ones for scientific agenda while analyzing their introduction into the real sector of economy. The present economic situation points out the necessity of much broader use of agricultural products not only for food production and food security, but also for the production of biomass as a source of raw materials for industry with the purpose of the production of new goods and services, including functional foods ${ }^{1}$ [Schmid, Padel, Levidow, 2012: 47]. The acceptance of such a way of thinking allowed forming the concept of bioeconomics, which on the one hand expands the traditional economic view of production activity, and on the other, stimulates the creation of new technologies for the production of innovative goods for new markets by using living microorganisms as an element of the technological system [Adamovich, 2016: 6].

Bioeconomics, from the point of view of scientific novelty and its justification as a new economic concept, is not actually like that, as it was a dominant sector of economy as far back as the pre-industrial era of economic management [Chernovalov, Chernovalova, 2019: 70]. From a scientific point of view, the long-standing concept of food economy, promoted by agricultural economists, is also standard. However, the development of science and technology creates new opportunities and makes bioeconomics one of the most influential factors in stimulating modern productive activities. The scientific public, forming an expanded concept of the previous standard approach, with their specific analytical and research tools, allowed businessmen-practitioners to form a dynamic sector of the European economy. The latter provides the largest number of workplaces and increases population employment, as well as has great potential and real foundations for future development. Proper management in this area in Belarus and in Brest region in particular, can have a great influence on the course of social and economic processes in society, and the results of its functioning will allow improving the well-being of the population.

The growth of the world population by 2050 will cause an increase in food demand by about $70 \%$, which may mean doubling the current level of meat consumption. The strategy for the development of bioeconomics should contribute to the development of knowledge leading to the growth in the production of basic foods, especially on the local scale of Brest region. Such a strategy should

\footnotetext{
${ }^{1}$ For example, sports nutrition for professional athletes.
} 
encourage changes in production ${ }^{2}$ and consumption patterns, encourage the spread of a healthy, more balanced diet and the production of different types of functional nutrition. Thus, for example, the European Union household sector generates about 90 million tons of waste from unreasonably purchased food during a year, an average of $180 \mathrm{~kg}$ per person per year [The Bioeconomy..., 2009: 77]. Here are the sources of increasing the efficiency of resources used connected with improving the organization of the management of logistic supply chains, which can limit losses. In the period of increasing competition in the market of biotechnological products and products of natural resources, there it becomes important not only the aspects of improving the efficiency of production organization, but also the issues of in-depth study of the logistic constituent in the analysis of existing and future supply chains of bioproducts [Adamovich, 2016: 12].

Thus, the development of bioeconomics is caused not only by the need for internal changes in the agricultural sector and processing industry, but also by the need to integrate science and business developing biotechnology on the local scale. This means that bioeconomics should be considered in an integrated manner, both at the micro- and meso- and macroeconomic levels, which requires this agenda should reach the regional, national, or interregional European level [Adamovich, 2016: 20].

\section{The concept of business-cluster and its application in bioeconomics}

The growing problem of the global food crisis at the beginning of the 21st century has made many foreign countries turn to innovative technologies. One of the most promising and widely introduced technologies today is agricultural biotechnology, or agrobiotechnology, which has formed the field of bioeconomics. There is a very understandable specific character of economy, management and organizational structures in the biotechnology sector, which implements a number of peculiarities in the logistics of its products. Economic research today identifies high-tech clusters based on know-how, clusters of cheap production and clusters of information services. It should be noted that in addition to high-tech clusters like Silicon Valley, biotechnological and other

\footnotetext{
${ }^{2}$ For example, introduction of digital bioclusters.
} 
clusters are developing actively. There is a large quantity of cluster programs which give an example of effective cooperation between science and business [Communication..., 2012: 80].

Among the most effective cluster initiatives in bioeconomics are the following: (Table 1).

Table 1. Leading cluster initiatives of the European Union in the field of bioeconomics

\begin{tabular}{|c|c|}
\hline Cluster Name & Cluster Location \\
\hline AgroBioCluster & Poland \\
\hline Anena Heidner & Norway \\
\hline Atlanpole Biotherapies & France \\
\hline BIOKON & Germany \\
\hline Biomedical Engineering Centre Cluster & Poland \\
\hline BioPark Regensburg GmbH & Germany \\
\hline Biopeople, Biocluster.dk & Denmark \\
\hline BioRegio STERN & Germany \\
\hline BioTech North & Norway \\
\hline BioTechMed Cluster Mazovia & Poland \\
\hline Biotechnology Innovation Base Cluster & Hungary \\
\hline BioTOP, Finnish Bioeconomy Cluster FIBIC & Finland \\
\hline Cluster Life Science Tirol & Austria \\
\hline GoteborgBIO & Sweden \\
\hline Grupo BioRioja & Spain \\
\hline
\end{tabular}

Source: authors' own development.

Scientific institutions are very often the initiators of bioeconomic clusters: they have scientific potential and experience, highly qualified staff, established relations with other research institutions and with industry both in their region and enterprises in other regions and countries. In some cases, scientific institutions become initiators of the creation of information above-cluster digital platforms. 
One of the examples of this form of innovation activity is the Danish innovation cluster site Biocluster.dk and Finnish Bioeconomic Cluster FIBIC (Table 1). The active use of consulting, strategic planning and coordination of the participants in the innovation process makes it possible to speak about the effectiveness of such innovative platforms in the support of cluster initiatives.

Thus, it can be stated that the formation of bioeconomic cluster structures allows a number of competitive advantages to be realized. As they quickly accumulate targeted resources, an accessible and accurate information base on market needs, technologies and scientific achievements is formed, and if the interests of management, owners and producers coincide, rapid breakthroughs in the innovative development of a certain region are possible. Due to the fact that the final product is created at the enterprises of the processing industry, the formation of food clusters in Belarus and Brest region in particular should be based on the study of their priority areas of their activity. The basic prerequisites for such assessment are scientific institutions, their scientific potential and experience, highly qualified staff, established relations with other research institutions; the availability and state of producing capacity of processing enterprises; the potential for growth in production and sales of certain types of food; the objective need to increase the competitiveness of enterprises; the initial state of the logistic infrastructure and its further development based on the future needs of the region, the country and the foreign market; the possibility to attract different types (including private) of investments in the basic capital. In order to identify enterprises on the basis of which it is advisable to create food bioclusters and organizations that can be included in their structure, we propose to apply SWOT-analysis of factors affecting the process of the creation of bioclusters in Brest region. The choice of an effective cluster development strategy is determined by both its strong and weak sides.

\section{SWOT-analysis of factors affecting the process of the creation of bioclusters in Brest region}

At present there are about 40 milk processing enterprises ${ }^{3}$ in Belarus. There is an increase in the concentration of dairy industry enterprises and the accession

\footnotetext{
${ }^{3}$ The largest enterprises of the sector: "Savushkin Product", "Babushka's Pot", "Milk Products", "Bellakt", "Milk Vitebsk", "Bereza Cheese Complex", "Slutsk Cheese Complex", "Glubokoe Milk Complex".
} 
of small and unprofitable enterprises to larger, efficiently working ones, transfer of shares owned by collective farms. Just recently in Belarus, it was planned to create a milk processing holding on the basis of 6 enterprises: the uniting center was planned to be the Public Corporation (PC) "Savushkin Product"4. However, the Government later abandoned plans to establish the holding company because of the recent tightening of competition in the domestic market, and the high saturation of the national market with dairy products contributes to its quality and lower prices. It should be noted that the competitiveness of the PC "Savushkin Product" has significantly increased due to the introduction of modern technologies that improve the quality of products, ensure longer shelf life and guarantee its safety for the consumer. At the same time, further development of this enterprise is seen in the adoption of organizational solutions of the digital bioeconomic cluster. As a result of SWOT-analysis, both favorable and unfavorable external events were revealed, which may affect the situation related to the formation of the cluster engaged in milk processing in Brest region. Of particular interest for this study are the infrastructure and logistic obstacles that adversely affect the formation of the biotechnological cluster in Brest region, as the task of clustering is turned into "point crowding". Therefore, the units in each cluster must be similar to each other and different from the units in other clusters.

A number of different clustering methods can be distinguished on the basis of the use of similarity matrices, evaluation of density functions of statistical distribution, heuristic algorithms, mathematical programming, etc. However, the analysis shows that the predominant part of these algorithms methodically comes from one precondition - the hypothesis of compactness, that is, the signs belonging to one and the same cluster are close to each other, and the measurements belonging to different classes are well divisible. The analysis has shown that the algorithms of cluster analysis should be formulated in terms of distances, which are presented as the distance among the units. As a measure of homogeneity of units, we have adopted a metric - Euclidean distance [Pilipuk, 2018: 132], which has certain advantages.

\footnotetext{
${ }^{4}$ In addition the holding would comprise PC "Bereza Cheese Complex", PC "City Milk Factory No. 2", PC "Kobrin Milk and Butter and Cheese Factory", PC "City Milk Factory № 1", and PC "Luninets Milk Factory", [online] https://investinbelarus.by/docs/21979.pdf [date of acces: 14.02.2020].
} 
Table 2. SWOT-analysis of the cluster potential of Brest region in the bioeconomic industry

\begin{tabular}{|c|c|}
\hline Strengths & Weaknesses \\
\hline $\begin{array}{l}\text { Geographical and transport location } \\
\text { - advantageous geographical position, } \\
\text { which promotes the development of } \\
\text { interregional and international relations } \\
\text { (the region is close to economically de- } \\
\text { veloped regions). }\end{array}$ & $\begin{array}{l}\text { Technological development } \\
\text { - out-of-date technologies in some biotech- } \\
\text { nological industries; } \\
\text { - insufficient level of labor productivity; } \\
\text { - lack of developed cooperation with ad- } \\
\text { vanced firms in Europe. }\end{array}$ \\
\hline $\begin{array}{l}\text { Natural conditions and resources } \\
\text { - favourable soil and climatic conditions; } \\
\text { - availability of raw materials for the de- } \\
\text { velopment of a factory-farm enterprise; } \\
\text { - skilled and relatively cheap labour force. } \\
\text { Economic, logistic and innovation potential } \\
\text { - availability of economic prerequisites for } \\
\text { cluster creation; } \\
\text { - scientific institutions, scientific potential } \\
\text { and experience, highly qualified staff, es- } \\
\text { tablished relations with other research } \\
\text { institutes; } \\
\text { - dynamism of the development of the real } \\
\text { sector of economy and high positions in } \\
\text { the markets of certain goods; } \\
\text { - a relatively broad network of financial and } \\
\text { credit institutions; } \\
\text { - developed regional infrastructure; } \\
\text { - international relations with the world } \\
\text { centers of bioeconomics and biotechno- } \\
\text { logies, which occupy the leading positions } \\
\text { according to the level of competitiveness } \\
\text { in the biotechnological sector. }\end{array}$ & $\begin{array}{l}\text { Inadequate development of logistic infrastru- } \\
\text { cture to ensure the development of bioeconomics } \\
\text { - infrastructure restrictions in the develop- } \\
\text { ment of biotechnologies (problems of de- } \\
\text { velopment of transport complex, energy, } \\
\text { lack of logistics); } \\
\text { - insufficient development of infrastructure } \\
\text { to attract investment. } \\
\text { Poor region's involvement in the global economy } \\
\text { - insufficient work in global markets other } \\
\text { than Russia, orientation towards its do- } \\
\text { mestic (regional) market; } \\
\text { - insufficient supplies of products to the } \\
\text { European Union; } \\
\text { - underdevelopment of international stan- } \\
\text { dards of quality of production and mana- } \\
\text { gement. } \\
\text { Unresolved social problems } \\
\text { - property differentiation of the popula- } \\
\text { tion; } \\
\text { - a large proportion of low-quality housing. }\end{array}$ \\
\hline
\end{tabular}

Source: authors' own development.

This method is an effective technique of similarity parameters grouping by estimating the distance between the units in the metric and the availability of logistic infrastructure, without which the concept of "cluster" itself is largely meaningless. An important reason for uniting the activity of different production structures is the decrease in transactional expenses as a result of the most effective coordination of work of possible participants (that is the presence of high value of the coefficient of institutional elasticity offered by professor A.V. Chernovalov) [Chernovalov, Solodukha, 2017: 67]. Such forms can be called economic clusters, which are based on a system of agreed economic interests. There are two large 
scientific institutions ${ }^{5}$ in Brest region, as well as the largest producer of dairy products in Belarus - the PC "Savushkin Product". The goods distribution network of the PC "Savushkin Product" includes 6 trade branches, a trade representation and more than 50 trade representatives on the territory of Belarus. The PC "Savushkin Product" has the right to supply dairy products to the European Union. The range of goods of "Savushkin Product" is characterized by a wide variety (more than 200 items), in addition, the company has passed certification to correspond to the new international scheme FSSC 22000 [Molochnaya..., 2014]. In this regard, taking into account the results of SWOT-analysis of the cluster potential of Brest region in the bioeconomic industry and the results of clustering calculations carried out by A.V. Pilipuk in the work "Competitiveness of food industry enterprises of Belarus in the conditions of building the Eurasian Economic Union" [Pilipuk, 2018: 132], where the k-medium method is applied and the specialized software package Statistica 6.0 is used, it has been revealed that five different clusters can operate in the Republic of Belarus, each of which has clear differences from other clusters. The first cluster, according to Pilipuk's research, includes seven enterprises with the largest market share in the category "casein" and having relatively high performance for goods such as butter and whole-milk products. The second cluster includes four enterprises that produce whole-milk products in large volumes - the PC "Savushkin Product" - 12.3\%, the PC "City Milk Factory No. 3" $-10.6 \%$, the PC "City Milk Factory No. 1" $-7 \%$, the PC "City Milk Factory No. 2" $-5 \%$ ), whereas the fourth cluster is a grouping comprising 41 enterprises with no marked specialization [Pilipuk, 2018: 132]. The enterprises included in the classes with the largest volumes of production by categories form the fifth cluster. The findings of the studies on clustering made it possible to describe qualitatively the selected set of enterprises, to propose the structure and composition of bioeconomic clusters in the milk-producing sub-complex of Brest region on the basis of the PC "Savushkin Product" and higher educational institutions of Brest.

\section{Digital methods of management in biocluster logistics}

Modern methods of management of physical and information flows in delivery chains such as Just-in Time, Quick Response, ECR (Effective Consumer Response), and the concepts of management of outsourcing, lean management, lean logistics

\footnotetext{
${ }^{5}$ Brest State Technical University and Brest State A.S. Pushkin University.
} 
require the formation of strategic cooperation units. The main motive for the formation of logistic chains and networks is the growth of competences understood and related for the whole system. The main point of this approach is to eliminate processes that do not add value to the product and to leave and attach those that create such value. In the context of logistic chains the creation of values added is based on the following principles (Andrews, Hahn, 1998: 52):

- disintermediation - elimination of all mediating units in the network;

- reintermediation - changing the role of intermediaries to better serve the rest of the participants of the network;

- infomediation - inclusion of new intermediaries having information resources and new knowledge in the network;

- role transformation - change the roles of specific network members or all at the same time;

- dematerialization - replacement of materials (reserves) and related with them assets (e.g. transport) by information;

- digitization - turning all processes into information models and multimedia databases and knowledge bases for use by all network members;

- resource exploitation - improvement of skills, competences, increase in asset values, development of structures and infrastructures within the logistic network.

Today, no enterprise, even the largest one, much less cluster structures, is able to compete with emerging and developing networks and existing within them supply chains. For the logistic chain to function and its results to be optimal in terms of time and cost, it must be managed effectively. At present, a new standard of organization of the logistic system of the enterprise, based on a systemic approach to supply chain management, is emerging, and the current economic and political situation highlights certain problem areas. First of all, it is a problem of "transparency" of logistic work. Many logistic chains exist within "grey" schemes, appearing on the legal surface in the form of small financial flows, which cannot always convince potential investors of the profitable placement of their assets in this group of companies. And yet high logistic costs, although very slowly, cause the imminent transfer of "grey" revenues to openly declared ones, which is necessary for external investment increase in this sector and on which the heads of enterprises do not always agree. The use of modern crypto currency allows, in our opinion, to solve this problem partially, on the one hand, by transferring payments for some freight forwarding services 
to bitcoins or other crypto currencies, and on the other, to use ICO $^{6}$ (Initial Coin Offering), to attract additional investment resources in logistic activities through crowdfunding ${ }^{7}$ [Chernovalov, 2017: 41].

As more and more participants in the global logistic market are puzzled by the increased transparency and reliability of supply chains, the leading IT companies are promoting the idea of using block chain ${ }^{8}$ technology for this purpose. Thus, IBM has already invited some large companies from various fields of activity to test their developments based on the principle of block chain. The transparency of the supply chain will benefit end-users, who will be able to receive evidence of the safety of the bioeconomic cluster products, its freshness, the absence of GMO and other undesirable additives. Blockchain makes processes more transparent: you can see who has money, how many coins are in circulation, how many tokens are bought, what the market price is. On the basis of the existing experience of using blockchain and crypto currencies, the authors have made an attempt to implement these technologies into the transport and expeditionary company Fantech", which serves the planned biocluster "Savushkin Product" [Chernovalov, 2017: 40].

With this purpose, the electronic online wallet for the firm was formed, which reflected the copies of all transactions that occurred in the blockchain network, starting from the very first (online and offline) ${ }^{10}$. Such a wallet is a place on the site where the registration was actualized, as well as an individual key was obtained, which is used to enter it ${ }^{11}$. In order to facilitate exchange procedures, the LiveCoin platform was chosen, which has a Russian-language interface, trades in crypto currencies against the dollar, the euro and the Russian ruble. You can purchase using the payment systems of Payeer, PerfectMoney, OkPay, Capitalist, SEPA and Wire Transfer are also available and you can withdraw money to Visa and MasterCard cards. The trade commission is flexible, dependent of turnover

6 The term "ICO" is formed by analogy with "IPO" (Initial Public Offering). The main differences between ICO and its original counterpart are the lack of strict government regulation and the lack of legal rights that shareholders receive.

${ }^{7}$ Crowdfunding is the collective collaboration of people who voluntarily pool their money or other resources over the internet to support the efforts of other people or organizations.

${ }^{8}$ Blockchain (or block chain) is a continuous sequential chain of blocks containing information built according to certain rules.

${ }^{9}$ Company specializes in international road transport from Belarus to Southwestern Europe.

10 Offline wallet is downloaded to a hard drive or other blockchain storage medium.

11 The wallet stores approved bitcoin transactions and its own balance. 
and ranges from $0.2 \%$ to $0.1 \%$. Sometimes you can use the analogue of the crypto exchange - localbitcoins.net. Here you can buy bitcoins directly from another individual for the currency of the country where you are. Each such transaction has a payment window, that is, the time during which it is possible to pay for this crypto currency, usually it can be set by the seller himself. After confirming the receipt of your payment, the seller sends you the "reserved" bitcoins - their number is shown in your wallet on the site, from where bitcoins can be taken to your online or offline wallet.

The next step in the development of digital technologies in the field of financial flows of logistic chains will be the access of Fantech to ICO (Initial Coin Offering). At the time of the emergence of the idea to go to ICO, that is the initial placement of coins (tokens), in the company at the final stage there was a standard logical product, which was planned to be put into production circulation on the basis of digital forwarding technology ${ }^{12}$. The world practice shows that for more than a year this is how Yojee (Singapore) startup works - this is a technology platform that provides logistic possibilities to manage supply chains, uses artificial intelligence and blockchain technology. It replaces the manager, monitors the status of orders in real time, generates accounts and manages tasks. The company says that it is already working with 30,000 vehicles and customers from Singapore, Australia, Cambodia and Indonesia. Before starting business negotiations to attract tokens, a detailed business plan was developed to introduce a new product into the production program. On the one hand, there were risks of lack of investment, on the other hand, a lot of opportunities were predicted, and there were also technological challenges: the need to link the traditional freight and expeditionary business to digital technologies in the financial sphere. In order to avoid mistakes and not to waste excessive time and funds the company moved according to a clearly well checked plan: a detailed structured report was prepared on the access to ICO, the schedule of connection and the cost of the main advertising channels, as well as the analysis of the modern world situation in the legal regulation of crypto currencies [Chernovalov, 2017: 40].

The ICO access process involves the development of the distribution code of investor shares and drawing up a crowdsale contract on Etherium or other platforms, creating a website to launch ICO based on successful English and Russian

12 Movement of goods (transport and expedition), courier and customs services, warehousing and inventory management, permanent transport, just-in-time deliveries, return packaging service, supply chain design and management, logistics consulting. 
Internet resources in this area, which is done on the basis of the original business plan. ICO is realized in the form of preliminary issue of its crypto currency by the company outside the procedures of mining or forging and distribution of this issue among the interested investors. Bitcoins and eothers can be exchanged for fiate money and in this way funds for the development of a project or technology can be received. In our project, the token will be tied to the US dollar to link the increase in the value of the company with the increase in the value of our crypto currency [Chernovalov, 2017: 40]. The cost of the token will be determined by the market and the activity of the work of the platform - the number of cars signed to it, their trips, provision of additional services, signed long-term contracts and partnership agreements. Investments in the project should be considered as a highly profitable instrument that will allow profitable financial transactions with non-financial assets and ensure profitable monetization from freight and logistics activities. Even with the lowest development factors of the company, taking into account all risks, the growth of the equity asset provides investors with profit at the expense of dividends or sale of its share of the investment asset of the company on crypto-currency exchanges. The profit depends on two factors: 1) the amount of interest that will be determined by the investment counts collected during the Token Sale company; 2) the real profit of the company, on whose growth directly the growth of the value of the internal token depends. The higher the profit of the company, the more important the token companies become in the crypto-currency market. The growth of the market price of the domestic token increases the interest in it as a currency for carrying out financial transactions in the market of non-fiate currencies, which will provide holders with additional income and the possibility of profitable sale of these assets, as well as digitalization of the logistic process.

\section{Conclusions}

1. The analysis made it possible to highlight the following main factors of successful development of cluster associations: stimulation of science and education, introduction of digital and technological innovations, strategic planning, export promotion, activity of cluster manager, mutual trust and intensity of interaction of subjects, availability of an informative web resource on the Internet.

2. We have identified among the latest modern tools: support for clusters with real or potential global demand; clear inter-agency coordination of manage- 
ment structures; reducing barriers to inter-cluster interaction and co-operation; highly qualified cluster management with appropriate payment and regular evaluation; implementation of regional specialization strategies.

3. The greatest positive impact has been revealed within the framework of regional development programs (structural reforms, regional competitive advantages, productivity and wage growth, etc.).

4. Modern supply chain management practices are inextricably linked to internal planning and resource optimization, that's why digital logistics is a concept that supports the firm's corporate strategy and is implemented in the information technology aspect as a certain "superstructure" over ERP/CSRP systems. New information and digital technologies in corporate ERP systems are based on the application of the ideology of supply chain management in real time - management with the use of EDI technologies, common packet of radio services (GPRS and the protocol of wireless applications) WAP, etc.

5. The range of possible applications of the concept of digital logistics expands when companies enter the electronic business. This process is particularly effective in the formed structures of bioeconomic clusters. Integrated logistics in this case is almost crucial in building a forward-looking relationship between the cluster's focus company and members of the supply chain.

\section{| References}

Adamowicz M., 2014, Europejska koncepcja biogospodarki i jej przełożenie na działania praktyczne, „Studia Ekonomiczne i Regionalne”, nr 7 (4), s. 5-21.

Andrews P., Hahn J., 1998, Transforming Supply chains into Value Webs, "Strategy \& Leadership" No. 26 (3), pp. 7-11.

Chernovalov P.A., 2017, Razvitie infrastruktury finansovykh potokov s ispolzovaniem blokcheina $v$ logistike, [v:] Ekonomika goroda $v$ period strukturnykh preobrazovanii: teoriya, metodologi, praktika: materialy mezhdunar. nauch.-prakt. konf., Moskva, 30 noyabrya 2017 g., $v 2$ ch., red. L.G. Rudenko, ch. 2, Moskva || Черновалов П.А., 2017, Развитие инфраструктуры финансовых потоков с использованием блокчейна в логистике, [в:] Экономика города в период структурных преобразований: теория, методологи, практика: материалы междунар. науч.-практ. конф., Москва, 30 ноября 2017 г., в 2 ч., ред. Л.Г. Руденко, ч. 2, Москва.

Chernovalov P.A., Chernovalova Zh.V., 2019, Bioekonomika: istoriya, soderzhanie, ekonomicheskaya mysl, "Vestnik Brestskogo universiteta”, No. 2, s. 70-75 || Черновалов П.А., 
Черновалова Ж.В., 2019, Биоэкономика: история, содержание, экономическая мысль, «Вестник Брестского университета», № 2, с. 70-75.

Chernovalov A.V., Solodukha P.V., 2017, Institucionalnoe izmerenie cifrovoi ekonomi$k i$, “Socialnaya politika i sociologiya”, t. 16, No. 2, s. 104-112 || Черновалов А.В., Солодуха П.В., 2017, Институциональное измерение цифровой экономики, «Социальная политика и социология», т. 16, № 2, с. 104-112.

Communication from the Commission to the European Parliament the Council, the European Economic and Social Committee and the Committee of the Regions. Horizon 2020 - The Framework Programme for Research and Innovation.COM (2011), 2012, European Commission, 808 final, Brussels 30.11.2011.

Molochnaya otrasl, 2014 || Молочная отрасль, [online] https://investinbelarus.by/ docs/-21979.pdf [date of access: 14.02.2020].

Pilipuk A.V., 2018, Konkurentosposobnost predpriyatij pishchevoj promyshlennosti Belarusi $v$ usloviyakh postroeniya Evrazijskogo ekonomicheskogo soyuza, Minsk ॥ Пилипук А.В., 2018, Конкурентоспособность предприятий пищевой промышленности Беларуси в условиях построения Евразийского экономического союза, Минск.

Schmid O., Padel S., Levidow L., 2012, The Bio-Economy Concept and Knowledge Base in a Public Goods and Farmer Perspective, "Biobased and Applied Economics", No. 1 (1), pp. 47-63.

The Bioeconomy to 2030 - Designing the Policey Agenda, 2009, OECD, Raport, [online] http:// www.europabio.org [date of access: 14.02.2020]. 